\title{
Adopting Sustainable Behavior in Institutions of Higher Education: A Study on Intentions of Decision Makers in the MENA Region
}

\author{
Dr. Sultan O. Almarshad ${ }^{1}$
}

\begin{abstract}
The aim of this study is to integrate the Protection Motivation and Habit theories to highlight and supplement the shortcomings of previous research. A systematic random sampling technique was employed to generate a sample of 1537 universities and colleges of MENA; a web questionnaire was emailed to the institutions, different analytical methods were used to analyse the data. The results show that (1) Protection Motivation Theory is valuable to apply specifically since it introduces the concept of coping appraisal, and (2) that Habit Theory is a suitable framework that can be employed to shed further insight on sustainable behaviour in higher education institutions. The findings both strengthen and expand previous knowledge on sustainable behaviour in higher education. Contrary to our expectations, habit does not moderate the relationship between all the dimensions of the cognitive process and the intention to adopt sustainability by decision makers.
\end{abstract}

Keywords Sustainability, Protection Motivation Theory, Habit Theory, Higher Education, Decision makers.

\section{Introduction}

While much research efforts have focused on assessing the adoption of sustainable environmental practices by organizations in developed countries, little has been undertaken in less developed countries (Belal and Cooper, 2011; Ozen and Kusku, 2009), such as the MENA region. Despite some initiatives towards more environmental reforms in the Arab countries in the Middle East and North Africa, in general, these countries are still lagging behind with respect to global standards in sustainable environment and development (Sakmar et al., 2011). In this regard, the role of higher educational institutions (HEIs) in the region to promote and adopt positive behavior and practices toward sustainable environment and development is imperative (Makrakis and Kostoulas-Makrakis, 2016).

Nowadays, HEIs are required to adopt, support, and implement practices of sustainability that consist more with their social goals and moral responsibilities toward making a fair, just and sustainable future (Disterheft et al. 2015). These institutions have more capacities to propose greater innovative ideas, undertake intrepid trialing, and contribute to the conception of original comprehension than other institutions (Cortese, 1992). HEIs play a critical role in assisting the transition to sustainability (Figueiró and Raufflet, 2015). They are major contributors in providing management development to assist managers to pilot the necessary organizational change for sustainability (Gitsham and Lenssen, 2009). 
A great body of research has identified organizational resistance to change as the main obstacle to the implementation of sustainable development (SD) in HEIs (e.g., Barth and Michelsen, 2013; Lozano et al. 2013). This resistance to change is often associated with a dominating old organizational culture that complicates the initiation of SD practices in HEIs (e.g., Shriberg and Harris 2012; Wright and Wilton 2012). Thus, the implementation of SD policies in HEIs is a multifaceted and complex process that comprises different cognitive activities and stages leading to motivated decisions. In this context, Kezar (2001) stresses the stipulation for better understanding of the need to change. Consequently, a fundamental question to be resolved in this respect is: which factors affect the adoption of SD policies and practices of HEI decision makers?

A few studies have applied some theories on the HEIs environment and empirically examined some motivational factors affecting sustainable oriented behaviors. Examples of such theories include Theory of Planned Behavior (Chen et al., 2011); the Social Norm Theory (Parece et al., 2013); the Value-Belief Norm Theory (Parece et al., 2013); the Identity Theory (Watson et al, 2015); and the Self-Determination Theory (Sintov et al., 2016). While these theories provide a logical base for understanding the structure and practices of SD, in general, they have not resulted in the assessment of the effects of the past behavior of individuals on threats and coping reactions. Understanding such effects can provide a great deal of insight for analyzing incentives and constraints for the implementation of SD and the directions of final outcomes in HEIs. In this direction, Protection Motivation Theory (PMT, Rogers, 1983) offers credible framework for approaching and analyzing issues related to the adoption of SD policies and practices because it incorporates the cognitive process with knowledge, experience, information, attitudes to behavior intentions and practical actions (Milne et al. 2000).

Although emergent studies on sustainable higher education institutions (SHEIs) offer significant insights, some limitations are noticeable:

First, most studies on sustainable higher education (SHE) are not founded on theories (Frynas and Yamahaki, 2016). This often includes details of implementation of specific programs (Sintov et al., 2016, Karp et al., 2016, Góes et al., 2016, Muller and Tempelhoff, 2016). The empirical focus of these studies can be explained by the pressing needs of communicating information in a speedily changing environment along with the cross academician-practitioner standpoints of several people interested by sustainability initiatives in HEIs. Therefore, testing and applying new theories in SHE is more than needed.

Second, in spite of the successful application of PMT across a large range of behaviors (Tesson et al., 2016, Doane et al., 2016, Bolkan and Goodboy, 2016), the theory has not been applied in the SHE context. Moreover, a remarkable deficiency of the model is its inability to explain the impact of past behavior on intention. Past behavior and Habit guide human behavior, making it difficult to change (Limayem et al. 2007). No studies have observed the contribution of Habit Theory on sustainable behavior. Therefore, further investigation is required in this area. This encouraged us to study habit within a sustainable behavior context along with an objective to extend the PMT.

Third, the behavioral theories that are applied are developed in the West (such as the PMT and Habit theories used in this study). Testing theories developed in the West in 
MENA region countries or in other developing countries would ensure the promotion of SHE throughout the world.

In the following, we provide a conceptual model of SHE and formulate hypotheses for promoting it throughout the world. Then, we detail the methodology and present the data analysis and results. We conclude with a discussion of the findings and offer their implications for the current research on SHE.

\section{Theoretical background}

Theory is the main basis for understanding the nature of things and nothing is practical as a good theory (Lewin, 1951). Theory often presents inclusive and reliable principles for the elucidation of perceptible phenomenon and can arrange interpretation and deal significantly with information that otherwise would be disordered as well as ineffective (Gitterman, 1988). It plays a significant role in the conduct of nearly any activity and SHE is no exception. Theory helps one avoid the error of a limited empiricism which concerns itself just with undirected data collection such as the case of the majority of the studies conducted on behavior change for SHE (see Appendix 1). SHE is a field with negligible attention toward theory since the accent has traditionally been on the descriptions of "best practices" mostly via assessing institutional activities, programs content, or students and teachers attitudes towards sustainability in practice (Viegas et al., 2016). Emergent studies on SHE are not constrained by a rigorous theoretical groundwork (Stephens and Graham, 2010), and very few investigations have been theory-guided (e.g., Chen et al., 2011, Parece et al., 2013, Watson et al., 2015, Sintov et al., 2016). This lack of theory-based SHE research may be one possible justification that sustainability has not been a main concern for all of the decision makers (Wright and Wilton, 2012). Moreover, even in the described practices and programs, no detailed information has been presented concerning the theories employed in the programs, and no information has been detailed to illustrate the role that theory has played in justifying the effect of practices. Accordingly, this study will apply the PMT and Habit theories to contribute to the foundation of both the general theory and practice of sustainable consumption and its specific applications in the MENA region.

\subsection{Conceptual model}

The initial conceptualization of PMT clearly considers that "past experience" and situational cues exert substantial influence on decision-making process (Rogers, 1975). Consequently, we theorized that habit is a driver of the cognitive mediating process of protection motivation. Simultaneously, the cognitive processing disappears over time in the presence of "automacity" and habit would come to hide the individual's mindset (Verplanken et al., 1997). This allowed us to assess the effect of the interaction among routinized past sustainable behavior and the threat appraisal and coping mechanisms theorized in PMT on the intention to adopt sustainable behavior in HEIs. Our integrated model is shown in Fig.1. 


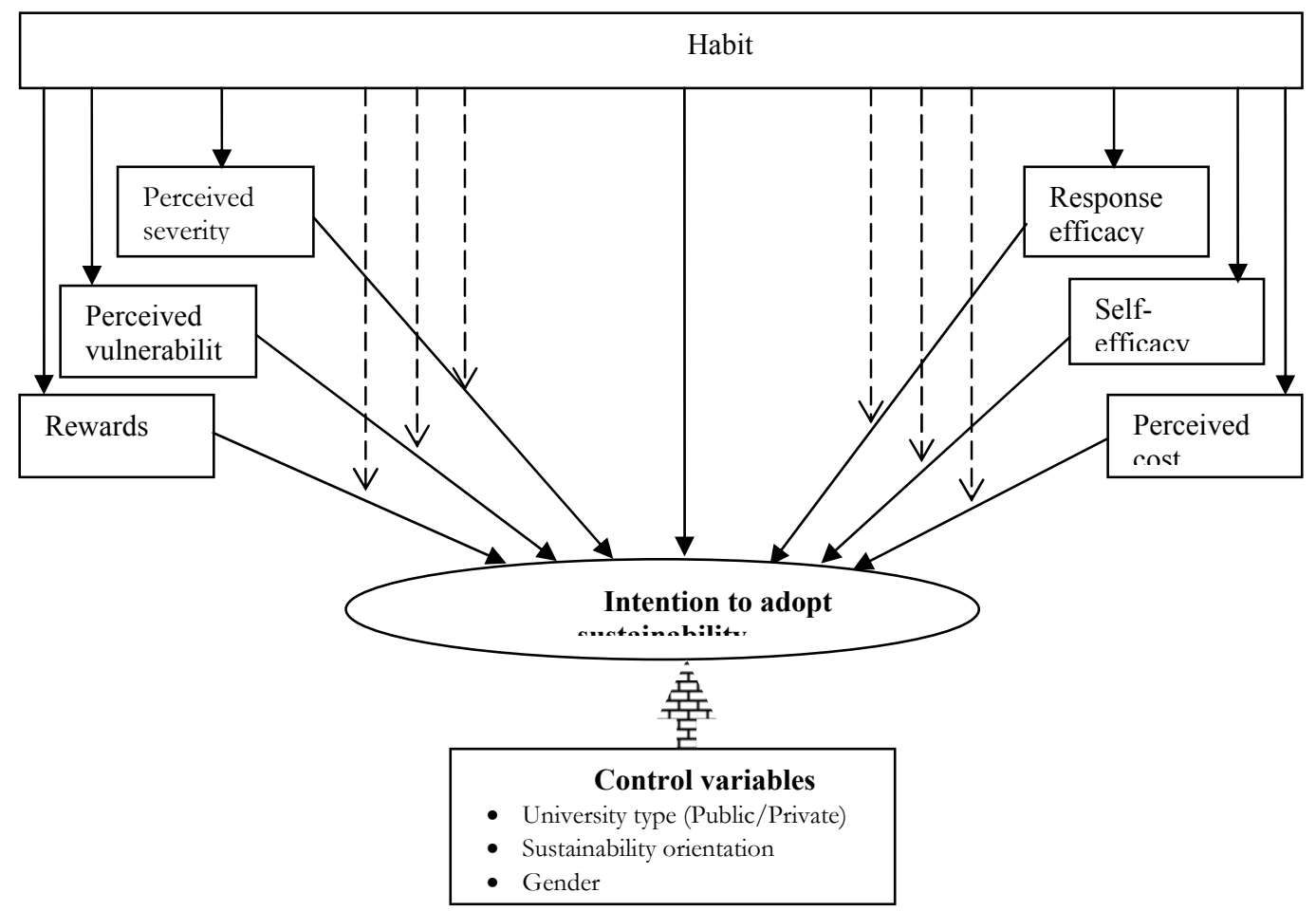

(1) Direct effect

(2) Moderator effect

Fig. 1. Conceptual model of the assumed (1) antecedent and (2) moderator effect of habit

\subsection{Protection Motivation Theory}

PMT (Rogers, 1975, 1983) is an inclusive theoretical model that is largely recognized and often utilized to guide human behavioral change. It was first proposed by Rogers in 1975 to recognize fear appeals and how individuals cope with them. PMT assumes that if individuals are faced by an obvious and existent threat and are given advices on how to avoid that threat (Perloff \& Ray, 1991), then they will adopt the desired behavior if they conclude that the advices are feasible and simple to adopt.

PMT supposes that information concerning a threat creates a cognitive mediating process in people that appraise positive or negative responses (Rogers, 1983). Therefore, we argue that the non-sustainable behavior of individuals represents a maladaptive response, whereas SD behavior is an adaptive response. The maladaptive response appeals to threat appraisal factors that reduce the probability of maladaptive response (Rogers, 1983), such as non-sustainable behavior. Threat appraisal is a mechanism concentrated on the question: is the threat menacing? It includes three dimensions: 
i. Perceived severity of the unwelcome consequences, which refers to an individual's feelings relating to the gravity of the negative event (Tsai et al., 2016). In our context, it refers to the gravity and the potential negative event attributable to the non-sustainable behavior. ii. Perceived vulnerability to the unwanted outcome, which denotes an individual's subjective perception of the menace that something awful will happen to him if no measures are used to avert it (Scarpa and Thiene,2011). In our study, threats occur from the negative consequences of the non-sustainable behavior of MENA universities; with regards to the climate change defies their region and the issues of environmental, economic and social concerns.

iii. Rewards, which result in any intrinsic or extrinsic incentive for growing or maintaining an undesirable behavior (Rogers, 1983), which in our context represent non-sustainable behavior. Rewards denote material or psychological contentment or peer appreciation, which boost the likelihood of a maladaptive response (Rogers, 1983). If a person sees that the reward for not accepting the coping response is superior than accepting it, then he will be less expected to adopt the coping response (Rogers, 1983).

PMT has been effectively applied in the health settings (Houlding and Davidson, 2003; Plotnikoff et al., 2009), natural hazards (Martin et al., 2007; Grothmann and Reusswig, 2006; Zaalberg and Midden, 2010), social issues and food safety (Cox and Bastiaans, 2007; Henson et al., 2010), water management (Kantola et al., 1983), climate change (Le Dang et al., 2014), environmental problems (Bubeck et al., 2012), and information security (Dang-Pham and Pittayachawan, 2015). Therefore, based on PMT and the existing literature, we hypothesized the following to be tested in the context of HEIs in the MENA region:

H1. Vulnerability positively affects intention to adopt sustainability.

H2. Perceived severity positively affects intention to adopt sustainability.

H3. Rewards negatively affect intention to adopt sustainability.

In addition, PMT is composed of coping appraisal dimensions, which rely on the boost of the adaptive response. The coping appraisal mechanism is focused on answering the question: Will my action help avoid or trim down the threat? (Woon et al. 2005). This is what primarily differentiates PMT from the numerous explorations of risk perceptions and human behavior in psychology (Grothmann and Reusswig, 2006). It includes three components:

i. Perceived response-efficacy, which refers to an individual's conviction that the desired behaviors will be successful in minimizing or eradicate the threat (Milne et al. 2000).

ii. Perceived self-efficacy, which refers to an individual's conviction that he has the aptitude to adopt the desired behavior(s) (Bandura, 1991).

iii. Perceived costs of the recommendations, which correspond to the totality of the obstacles to engaging in the desired behavior (Scarpa and Thiene, 2011), counting economic costs and noneconomic costs such as time, effort, inconvenience, and discomfort.

Hence, based on PMT and the existing literature, we propose the following hypotheses to be tested in the study context:

H4. Perceived response-efficacy positively affects intention to adopt sustainability.

H5. Perceived self-efficacy positively affects intention to adopt sustainability.

H6. Perceived costs negatively affect intention to adopt sustainability. 


\subsection{Habit as an antecedent of intention to adopt sustainability}

Habits are a form of past, routinized and automatic behavior (Ouellette \& Wood, 1998; Ronis, Yates, \& Kirscht, 1989). Several daily goal-directed behaviors are executed in a habitual manner (Verplanken \& Aarts, 1999). The repeating activities generate a routine response, such that the activities come under the influence of stimulus cues and are done mechanically with modest mindful awareness (Triandis, 1977). Habits are progressively laid down in the ritual memory during repeated activities and their development necessitates practice. So, the cognitive process leading to decision may lose its predictive strength (Ouellette and Wood, 1998). In agreement, Verplanken et al. (1997) show that habit decreases the pomposity of choice tactics in decision-making. Verplanken and Orbell (2003) affirm that habit cannot be evaluated with an assessment of past behavior or behavioral frequency since behavioral frequency alone does not identify the automatic nature of habit. So, they develop a measurement model called the Self-Reported Habit Index (SRHI) that distinguishes the core component of the habit construct: "automaticity". Habit is a psychological concept sooner than behavioral reappearance (Verplanken and Orbell, 2003).

According to Ajzen (2002), there is an unnecessary connection between incidence of past behavior and the habitual intensity of that behavior. Past behavior may forecast later behavior based on other constant variables over time (Aarts et al., 1998; Bamberg et al., 2003). The influence of former behavior can reproduce common method variance (Ajzen, 1991) because similar response arrangements are usually employed for behavioral considerations at both time-points. Accordingly, behavioral repetition does not form direct confirmation for regular processes (Bamberg et al., 2003; Verplanken \& Orbell, 2003). The SRHI offers useful insight concerning the past behavior - actual behavior relationship. For example, using SRHI, Verplanken (2006) confirms the presence of a mediation between the two types of behavior, which denotes that habit is a practical elucidation of the residual variance problem (Ajzen, 2002a). Moreover, Brug et al. (2006) show that the integration of habit strength in a hierarchical model significantly enhances its explained variance.

According to PMT, past experience comprises feedback from private experiences with targeted maladaptive and adaptive responses (Milne et al., 2000). Habit theory asserts that several responses take place without mindful decision (Verplanken \& Aarts, 1999) and are performed since individuals are familiar with the ways to do them (Hull, 1943; Tolman, 1932). Generally, recurring behavior is more influenced by situational cues than cognizant decision making (Aarts and Dijksterhuis, 2000). In addition, the initiation of a novel behavior necessitates a mindful decision and the novel behavior will progressively turn out to be automatic (Bargh \& Gollwitzer, 1994; Verplanken \& Aarts, 1999). Cues that activate automatic behavior are copious, obvious and steady (Verplanken, Aarts, van Knippenberg, \& Moonen, 1998). Since situational cues relay directly to habitual behavior (Verplanken and Orbell, 2003), then consciousness of threats generates the cognitive process (in our study, the PMT process), which initiates behavioral intentions. Automatic behavior is not exclusively caused by behavioral sequence but by a set of objectives and the resources employed to attain these objectives (Guinea and Markus, 2009). Hence, we hypothesize that habitual sustainable behavior has a negative effect on response cost and rewards but is positive for all the rest of the concepts of PMT. Thus, practicing the habit 
of sustainable behavior reduces both the rewards for non-sustainable behavior and the response cost (e.g., time, effort, inconvenience, and discomfort), that will have a positive effect on perceived severity, perceived self-efficacy, response efficacy, and perceived vulnerability.

Prior studies support the direct effects of past behavior on present behavior, even when cognitions are considered (Conner \& Abraham, 2001; De Bruijn et al., 2006; Hagger, Chatzisarantis, \& Biddle, 2001; Jackson, Smith, \& Conner 2003; Rhodes \& Courneya, 2003) and a significant relationship was established between past behavior and behavioral intention (Kashima et al., 1993; O’Callaghan et al., 1997; Thøgersen, 2002).

Therefore, we tested the following antecedence hypotheses:

H7a. Habit positively affects intention to adopt sustainability.

H7b. Habit positively affects perceived vulnerability.

H7c. Habit positively affects perceived severity.

H7d. Habit negatively affects rewards.

H7e. Habit positively affects perceived response efficacy.

H7f. Habit positively affects perceived self-efficacy.

H7g. Habit negatively affects perceived costs.

\subsection{Habit as a moderator of the relationship between the cognitive processes and the intention to adopt sustainability}

Ouellette and Wood (1998) illustrate two methods in which past behavior may control future behavior. First, past individual experience may bestow information that forms attitudes and beliefs; in sequence, the past behavior will establish the future behavior (i.e. a mindful response). Consistent with this logic, the effect of past behavior is supposed to be mediated by the PMT. Second, reproducing a behavior may lead to the development of a habitual response; consequently, the behavior turns out to be under the control of stimulus cues and is carried out instinctively with modest consciousness. In such a situation, cognitive processes such that the PMT components may mislay their predictive strength. Hence, once past behavior is found to have a direct influence on future behavior in addition to the effect of social cognitive cues, this is considered as proof that the behavior is under habitual control. Since behaviors recur and turn out to be more habitual, their performance must rely less on a rational statement of the person's intentions than on their past behavior (Norman and Conner, 2006). In agreement with this logic, Verplanken et al. (1997) affirm that habit minimizes the importance of data collection and the rigor of choice strategies in decision-making. Triandis (1980) asserts that when habit strength for some behavior rises, this behavior must be less elaborated by mindful intentions. Although interactions or so-called moderator analyses are comparatively rare in the literature (Sheeran, 2002), assessing the interaction of habit and the cognitive processes is a valuable complement to exhibitions that behavior is a subject of habit or cognitive processes.

Previous studies have assessed the moderating role of habit. For example, Limayem et al. (2003) show that habit moderates the relationship between intention and continuance behavior. Khalifa and Liu (2007) focus on the moderating role of habit in the relationship between satisfaction and intention. Their findings indicated that satisfaction may not be a main cause of intention with the lack of habit. This means that the 
intention is more dependent on the development of the habit itself (Chiu et al., 2012). In line with this logic, Hsu et al. (2015) stress that perceived value has stronger impact on intention for high-habit individuals, while trust and satisfaction have higher effects on intention for low-habit individuals. Thus, we hypothesized:

H8a. Habit will decrease the influence of perceived severity on intention to adopt sustainability.

H8b. Habit will decrease the influence of perceived vulnerability on intention to adopt sustainability.

H8c. Habit will increase the influence of rewards on intention to adopt sustainability.

H8d. Habit will decrease the influence of response-efficacy on intention to adopt sustainability.

H8e. Habit will decrease the influence of self-efficacy on intention to adopt sustainability.

H8f. Habit will increase the influence of perceived cost on intention to adopt sustainability.

\section{Research methodology}

\subsection{Data collection}

$S=Z \sqrt{\frac{p(1-p)}{n}} \sqrt{\frac{N-n}{N-1}}$

Where:

$\mathrm{Z}=$ degree of required confidence $(95 \%)$

$\mathrm{S}=$ sample error $(5 \%)$

$\mathrm{p}=$ ratio of population characteristics available in the sample $(50 \%)$

$\mathrm{N}=$ population size

$\mathrm{n}=$ sample size

Seeing that the sample size, calculated based on the Aaker and Day (1986) equation, was somewhat small $(\mathrm{n}=90)$, it decided to represent $15 \%$ of the population, not only since this is acknowledged by the majority of researchers but furthermore so as to enhance the sample confidence and reduce the sample error. Thus, a systematic random sampling technique was employed to generate a sample of 1537 institutions. An anonymous web questionnaire was emailed to the institutions. The questionnaire was prepared in such a manner that approximately 10 minutes were sufficient to complete it. 667 questionnaires were returned. Regrettably, no information is obtainable concerning the nonrespondents. Thus, this cause of non-sampling inaccuracy cannot be supervised. 78 incomplete responses were excluded from the analyses, leaving 589 useful questionnaires $(38.32 \%)$. Efforts were made to contact all institutions up to three times before removing them from the study. Since 589 cases were collected, this sample size is a very satisfactory one because having 10 observations per item is suggested in the SEM approach (Bartlett et al., 2010). Most respondents were males (76.1\%). The majority were younger than 45 years old $(66.3 \%) .18$ countries participated in the study, including: Saudi Arabia (14.7\%), Egypt (13.1\%), Algeria (11.8\%), Tunisia (11.7\%), United Arab Emirates (10.3\%), Oman (7.5\%), Jordan (6.5\%), Morocco (4.3\%), Sudan (4.1\%), Kuwait 
(4 \%), Bahrain (2.6), Lebanon (3.3\%), Qatar (2.1\%), Palestine (2.4\%), and four politically unstable countries (Syria, Libya, Iraq, and Yemen, 1.6\%). Of the participants who agreed to participate in the study, $68 \%$ were from publicly funded institutions, and $32 \%$ were from private universities/colleges. To ensure that the selected questionnaires were representative of the total population, a non-response bias test was performed to compare between the first and last responses. Chi-2 tests indicated no differences between the two groups, indicating that a non-response bias was not an issue.

\subsection{Research instrument development-measures}

All constructs were measured by multiple-item scales adapted from past studies (Table 1).

Table 1 Measurement items $(\mathrm{N}=589)$

\begin{tabular}{|c|c|c|c|c|c|}
\hline Constructs & Items & $\begin{array}{l}\text { Loadings' } \\
\text { range }\end{array}$ & $\begin{array}{l}\text { Composite } \\
\text { reliability }\end{array}$ & $\begin{array}{l}\text { Cronbach's } \\
\text { alpha }\end{array}$ & $\overline{\text { AVE }}$ \\
\hline \multirow{12}{*}{$\begin{array}{l}\text { Habit } \\
\text { Verplanken } \\
\text { and Orbell } \\
(2003)\end{array}$} & $\begin{array}{l}\text { Sustainable behavior is something I } \\
\text { do frequently. }\end{array}$ & \multirow[t]{12}{*}{$\begin{array}{l}0.675- \\
0.731\end{array}$} & \multirow[t]{12}{*}{0.77} & \multirow[t]{12}{*}{0.77} & \multirow[t]{12}{*}{0.53} \\
\hline & $\begin{array}{l}\text { Sustainable behavior is something I } \\
\text { do automatically. }\end{array}$ & & & & \\
\hline & $\begin{array}{l}\text { Sustainable behavior is something I } \\
\text { do without having to consciously } \\
\text { remember. }\end{array}$ & & & & \\
\hline & $\begin{array}{l}\text { Sustainable behavior is that which } \\
\text { makes me feel weird if I do not do it. }\end{array}$ & & & & \\
\hline & $\begin{array}{l}\text { (a) Sustainable behavior is something I } \\
\text { do without thinking. }\end{array}$ & & & & \\
\hline & $\begin{array}{l}\text { Sustainable behavior is something } \\
\text { that would require effort not to do. }\end{array}$ & & & & \\
\hline & $\begin{array}{l}\text { Sustainable behavior is something } \\
\text { that belongs to my (daily, weekly, } \\
\text { monthly) routine. }\end{array}$ & & & & \\
\hline & $\begin{array}{l}\text { (b) Sustainable behavior is something } \\
\text { that I start doing before I realize I'm } \\
\text { doing it. }\end{array}$ & & & & \\
\hline & $\begin{array}{l}\text { Sustainable behavior is something } \\
\text { that I would find hard not to do. }\end{array}$ & & & & \\
\hline & $\begin{array}{l}\text { (a) Sustainable behavior is something } \\
\text { that I have no need to think about } \\
\text { doing. }\end{array}$ & & & & \\
\hline & $\begin{array}{l}\text { Sustainable behavior is something } \\
\text { that's typically 'me'. }\end{array}$ & & & & \\
\hline & $\begin{array}{l}\text { Sustainable behavior is something } \\
\text { that I have been doing for a long } \\
\text { time. }\end{array}$ & & & & \\
\hline \multirow{4}{*}{$\begin{array}{l}\text { Vulnerability } \\
\text { (Bockarjova \& } \\
\text { Steg, 2014; } \\
\text { Plotnikoff \& } \\
\text { Higginbotham, } \\
\text { 2002) }\end{array}$} & $\begin{array}{l}\text { My chances of living negative } \\
\text { experience, associated with the }\end{array}$ & \multirow[t]{4}{*}{$\begin{array}{ll}0.711 \quad- \\
0.794\end{array}$} & \multirow[t]{4}{*}{0.78} & \multirow[t]{4}{*}{0.78} & \multirow[t]{4}{*}{0.69} \\
\hline & $\begin{array}{l}\text { consequences of non-sustainable } \\
\text { behavior, are high. }\end{array}$ & & & & \\
\hline & $\begin{array}{l}\text { Non-sustainable behavior will threat } \\
\text { my well-being. }\end{array}$ & & & & \\
\hline & $\begin{array}{l}\text { Non-sustainable behavior will } \\
\text { negatively affect my quality of life. }\end{array}$ & & & & \\
\hline Perceived & Non-sustainable & 0.816 & 0.76 & 0.74 & 0.68 \\
\hline
\end{tabular}




\begin{tabular}{|c|c|c|c|c|c|}
\hline \multirow{5}{*}{$\begin{array}{l}\text { severity } \\
\text { (Bockarjova \& } \\
\text { Steg, 2014; } \\
\text { Axsen, 2010) }\end{array}$} & $\begin{array}{l}\text { negative effects on physical and } \\
\text { cultural resources. }\end{array}$ & \multirow[t]{5}{*}{0.895} & & & \\
\hline & $\begin{array}{l}\text { Non-sustainable behavior is a threat } \\
\text { to animal and plant species. }\end{array}$ & & & & \\
\hline & $\begin{array}{l}\text { Non-sustainable behavior is a threat } \\
\text { to my individual and social } \\
\text { environment. }\end{array}$ & & & & \\
\hline & $\begin{array}{l}\text { Non-sustainable behavior is a threat } \\
\text { to safety of present and future } \\
\text { human generations. }\end{array}$ & & & & \\
\hline & $\begin{array}{l}\text { Non-sustainable behavior has } \\
\text { negative effects on the quality of life. }\end{array}$ & & & & \\
\hline \multirow{2}{*}{$\begin{array}{l}\text { Rewards } \\
\text { Yan, Jacques- } \\
\text { Tiura, Chen, } \\
\text { Xie, Chen, } \\
\text { Yang, \& } \\
\text { MacDonell } \\
\text { (2014); Vance, } \\
\text { Siponen, \& } \\
\text { Pahnila, (2012) }\end{array}$} & $\begin{array}{l}\text { Non-sustainable behavior is easy, } \\
\text { effortless and uncomplicated. }\end{array}$ & \multirow[t]{2}{*}{$\begin{array}{l}0.901 \\
0.985\end{array}$} & \multirow[t]{2}{*}{0.71} & \multirow[t]{2}{*}{0.72} & \multirow[t]{2}{*}{0.57} \\
\hline & $\begin{array}{l}\text { With non-sustainable behavior, I } \\
\text { would save time, money, effort... }\end{array}$ & & & & \\
\hline \multirow{4}{*}{$\begin{array}{l}\text { Perceived } \\
\text { response- } \\
\text { efficacy } \\
\text { Bockarjova \& } \\
\text { Steg (2014); } \\
\text { Axsen (2010); } \\
\text { Plotnikoff \& } \\
\text { Higginbotham } \\
(2002)\end{array}$} & $\begin{array}{l}\text { I am sure that sustainable behavior is } \\
\text { effective in preventing, conserving } \\
\text { and preserving physical and cultural } \\
\text { resources. }\end{array}$ & \multirow[t]{4}{*}{$\begin{array}{l}0.891 \\
0.937\end{array}$} & \multirow[t]{4}{*}{0.73} & \multirow[t]{4}{*}{0.74} & \multirow[t]{4}{*}{0.51} \\
\hline & $\begin{array}{l}\text { I am sure that sustainable behavior } \\
\text { will help prevent depletion of animal } \\
\text { and plant species. }\end{array}$ & & & & \\
\hline & $\begin{array}{l}\text { I am sure that sustainable behavior } \\
\text { will help prevent my individual and } \\
\text { social environment. }\end{array}$ & & & & \\
\hline & $\begin{array}{l}\text { I am sure that sustainable behavior } \\
\text { will help prevent threat to safety of } \\
\text { present and future human } \\
\text { generations. }\end{array}$ & & & & \\
\hline \multirow{3}{*}{$\begin{array}{l}\text { Perceived self- } \\
\text { efficacy } \\
\text { Zhao, } \\
\text { Cavusgil, \& } \\
\text { Zhao (2016); } \\
\text { Lin \& Hsu } \\
(2015)\end{array}$} & Self-monitoring. & \multirow{3}{*}{$\begin{array}{l}0.877 \\
0.974\end{array}$} & \multirow[t]{3}{*}{0.84} & \multirow[t]{3}{*}{0.84} & \multirow[t]{3}{*}{0.73} \\
\hline & Self-esteem. & & & & \\
\hline & Self-preference. & & & & \\
\hline \multirow{4}{*}{$\begin{array}{l}\text { Perceived } \\
\text { costs } \\
\text { (Bockarjova \& } \\
\text { Stern, 2014) }\end{array}$} & Sustainability requires additional cost. & \multirow{4}{*}{$\begin{array}{l}0.747 \\
0.824\end{array}$} & \multirow[t]{4}{*}{0.87} & \multirow[t]{4}{*}{0.88} & \multirow[t]{4}{*}{0.74} \\
\hline & $\begin{array}{l}\text { Sustainability, often, has limited range } \\
\text { (less options, less choices...) }\end{array}$ & & & & \\
\hline & $\begin{array}{lll}\begin{array}{l}\text { Sustainability requires } \\
\text { change. }\end{array} & & \text { behavioral } \\
\end{array}$ & & & & \\
\hline & $\begin{array}{l}\text { There are uncertainly aspects of } \\
\text { sustainable behavior. }\end{array}$ & & & & \\
\hline \multirow{2}{*}{$\begin{array}{l}\text { Intention to } \\
\text { adopt } \\
\text { sustainability. } \\
\text { (Chen et al., } \\
\text { 2011, Ajzen, }\end{array}$} & $\begin{array}{l}\text { I intend to adopt more sustainable } \\
\text { behavior in my operation during the } \\
\text { next year. }\end{array}$ & \multirow[t]{2}{*}{$\begin{array}{ll}0.747 \\
0.818\end{array}$} & \multirow[t]{2}{*}{0.74} & \multirow[t]{2}{*}{0.74} & \multirow[t]{2}{*}{0.66} \\
\hline & $\begin{array}{l}\text { I will try to adopt sustainable } \\
\text { behavior in my operation during the }\end{array}$ & & & & \\
\hline
\end{tabular}




\begin{tabular}{|c|c|c|c|c|c|}
\hline \multirow[t]{2}{*}{ 1988) } & next year. & & & & \\
\hline & $\begin{array}{l}\text { I plan to adopt sustainable behavior } \\
\text { during the next year. }\end{array}$ & & & & \\
\hline \multirow{5}{*}{$\begin{array}{l}\text { Sustainability } \\
\text { orientation } \\
\text { (Kuckertz, M. } \\
\text { Wagner) }\end{array}$} & $\begin{array}{l}\text { Universities/Colleges should take a } \\
\text { leading role in environmental } \\
\text { protection. }\end{array}$ & \multirow[t]{5}{*}{$\begin{array}{l}0.7690 \\
0.825\end{array}$} & \multirow[t]{5}{*}{0.70} & \multirow[t]{5}{*}{0.73} & \multirow[t]{5}{*}{0.60} \\
\hline & $\begin{array}{l}\text { (b) Universities/Colleges that are } \\
\text { environmentally oriented have } \\
\text { advantages in recruiting and retaining } \\
\text { qualified staff. }\end{array}$ & & & & \\
\hline & $\begin{array}{l}\text { Social responsibility should be part of } \\
\text { the foundations of each } \\
\text { university/college. }\end{array}$ & & & & \\
\hline & $\begin{array}{l}\text { I think that environmental problems } \\
\text { are the biggest challenges for our } \\
\text { society. }\end{array}$ & & & & \\
\hline & $\begin{array}{l}\text { I think that universities/colleges need } \\
\text { to take on a larger social } \\
\text { responsibility. }\end{array}$ & & & & \\
\hline
\end{tabular}

(a) Item eliminated based on purification procedure.

(b) Item eliminated based on specification measurement model.

\subsection{Tests for common method bias}

A common method bias may occur since data were simultaneously collected from a single source (Podsakoff et al., 2003). Thus, the study imposed a procedural solution at the data collection stage; consequently, item ambiguity was reduced, and the data were mixed in the questionnaire. Then, we conducted a PCA on all our constructs with no rotation, resulting in the emergence of nine components with Eigenvalues greater than 1. A total explained variance of $71 \%$ was achieved, signifying that the common method bias should not affect the results.

\section{Analysis and Results}

\subsection{Evaluating control variables}

The impacts of three control variables were analyzed: public/private sector, gender and sustainability orientation. A one-way ANOVA shows that the intentions to adopt sustainable behavior differed significantly according to the type of university/college (mean 3.6, $\mathrm{p}<0.03$ ). In the private sector, decision makers were most likely to accept sustainable behavior. Correspondingly, we found that sustainability orientation significantly correlated with intention $(\mathrm{r}=0.187, \mathrm{p}<0.05)$. This demonstrates that the decision makers' philosophy towards sustainability significantly influences their behavioral intentions. Respondents with a high level of orientation are more intent to adopt sustainable practices in their institutions than those having less environmental sustainability orientation. Moreover, in spite of the fact that research on gender differences has shown remarkable dissimilarities between women and men, the result shows significant invariance across the two groups. Gender is not a significant factor in the decision makers' intention model. In that sense, similar psychological mechanism seems to operate for males as well as for females concerning the subject of the adoption of sustainability in HEIs. 


\subsection{Habit as an antecedent to Intention to adopt sustainability in higher education}

Mediation effects were analyzed following four steps (Baron \& Kenny, 1986). A construct may be considered a mediator to the extent to which it transmits the effect of an independent variable (IV) to a dependent variable (DV). Normally, mediation occurs if (1) the habit significantly influences the intention in the nonexistence of the mediator; (2) the habit significantly influences the mediator; (3) the mediator has a significant unique influence on the intention, and (4) the impact of the habit on the intention disappears upon the addition of the mediator to the model. Complete mediation occurs when the effect of habit on intention to adopt sustainability is nil after controlling for cognitive processes in Step 4. To assess the complete mediation model, we carried out the Sobel test (Sobel, 1982) via an interactive website (http:/ quantpsy.org/sobel/sobel.htm) by Preacher and Leonardelli (2008). Findings are presented in Table 2.

Table 2. Habit as an antecedent of intention to adopt sustainable behavior (hierarchical regression analysis, $\mathrm{n}=589$ )

\begin{tabular}{|c|c|c|c|c|c|c|c|c|}
\hline Predictor variable & $\begin{array}{l}\text { Step 1: } \\
\text { IV --> } \\
\text { DV } \\
\text { F }\end{array}$ & B & $\begin{array}{l}\text { Step } \\
2: \\
\text { IV } \quad- \\
> \\
\text { Med } \\
\text { F }\end{array}$ & $\mathrm{B}$ & $\begin{array}{l}\text { Step 3: } \\
\text { Med --> } \\
\text { DV } \\
\text { B }\end{array}$ & $\begin{array}{l}\text { Step 4: } \\
\text { IV --> } \\
\text { DV } \\
\text { B }\end{array}$ & $\begin{array}{l}\text { Full } \\
\text { model } \\
\text { R2 }\end{array}$ & $\begin{array}{l}\text { Sobel } \\
\text { test } z- \\
\text { value }\end{array}$ \\
\hline $\begin{array}{l}\text { DV: Intention } \\
\text { IV: Habit } \\
\text { Med: Perceived } \\
\text { severity }\end{array}$ & $15.73^{* *}$ & $0.35^{* *}$ & 13.44 & $0.26^{*}$ & $0.49^{* *}$ & $0.18^{*}$ & $0.33^{* *}$ & $3.27 * *$ \\
\hline $\begin{array}{l}\text { DV: Intention } \\
\text { IV: Habit } \\
\text { Med: Perceived } \\
\text { vulnerability }\end{array}$ & $15.73^{* *}$ & $0.35^{* *}$ & 11.89 & $0.19^{*}$ & $0.37 * *$ & $0.15^{*}$ & $0.30 * *$ & $0.25^{* *}$ \\
\hline $\begin{array}{l}\text { DV: Intention } \\
\text { IV: Habit } \\
\text { Med: Rewards }\end{array}$ & $15.73^{* *}$ & $0.35^{* *}$ & 18.62 & $-0.39 * *$ & $-0.16^{*}$ & $-0.13^{*}$ & $0.11 *$ & $-1.02^{*}$ \\
\hline $\begin{array}{l}\text { DV: Intention } \\
\text { IV: Habit } \\
\text { Med: Response- } \\
\text { efficacy }\end{array}$ & $15.73^{* *}$ & $0.35^{* *}$ & 9.04 & $0.15^{*}$ & $0.33^{* *}$ & $0.19 *$ & $0.22 *$ & $2.72^{* *}$ \\
\hline $\begin{array}{l}\text { DV: Intention } \\
\text { IV: Habit } \\
\text { Med: Self-efficacy }\end{array}$ & $15.73^{* *}$ & $0.35^{* *}$ & 10.17 & $0.21 *$ & $0.29 * *$ & $0.18^{*}$ & $0.20^{*}$ & $2.11 * *$ \\
\hline $\begin{array}{l}\text { DV: Intention } \\
\text { IV: Habit } \\
\text { Med: Perceived } \\
\text { cost }\end{array}$ & $15.73^{* *}$ & $0.35^{* *}$ & 10.88 & $-0.17 *$ & $-0.20^{*}$ & $-0.16^{*}$ & $0.12^{*}$ & $-1.44^{*}$ \\
\hline
\end{tabular}

Note: Steps of mediation analysis (Baron and Kenny, 1986; Judd and Kenny, 1981). The Sobel test (Sobel, 1982) was performed on the website of Preacher and Leonardelli (2008). ${ }^{*} p<0.05,{ }^{*} p<0.01$.

The findings show that habit is directly related to intention to adopt sustainable behavior in HEIs (Step1). But note that Step 1 is not indispensable for mediation to happen (e.g., Kenny et al. 1998). Step 2, 3 and 4 confirm that there was a partial mediation for habit: It 
affects the cognitive processes represented by the full PMT model (perceived severity, perceived vulnerability, rewards, response-efficacy, self-efficacy, and perceived cost), thereby impacting on intention.

The findings of the hierarchical regression analysis support the hypotheses $\mathrm{H} 1, \mathrm{H} 2, \mathrm{H} 3$, $\mathrm{H} 4, \mathrm{H} 5$, and $\mathrm{H} 6$ and confirm, therefore, the success of the protection motivation theory in predicting decision makers' intention toward the adoption of sustainability in HEIs. As a consequence, the present study extends the application of this theory to a new context and shows that PMT is valuable to apply particularly because it introduces the concept of coping appraisal.

In addition, the hierarchical regression analysis results support the antecedence hypotheses of habit H7a, H7b, H7c, H7d, H7e, H7f, and H7g. We found that habit has a significant effect on intention and on all components of PMT. While this result corroborates the theory, we found no empirical studies that have investigated these relationships between habit and the PMT in the general setting of sustainable development, and in the specific context of higher education. Moreover, past research has not examined the effect of automatic behavior on sustainable behavior.

\subsection{Habit as a moderator of the relationship between cognitive processes and intention to adopt sustainability}

Moderating effects were assessed via moderated multiple regression analyses (Aiken \& West, 1991). The findings are presented in Table 3.

Table 3. Habit as moderator of the relation between the cognitive processes components and the intention to adopt sustainable behavior $(\mathrm{n}=589)$

\begin{tabular}{|c|c|c|}
\hline & & $\begin{array}{l}\text { Dependent variable: } \\
\text { Intention } \\
\text { B }\end{array}$ \\
\hline \multirow{6}{*}{ Step 1} & Perceived severity & $0.49 * *$ \\
\hline & Perceived vulnerability & $0.37 * *$ \\
\hline & Rewards & $-0.16^{*}$ \\
\hline & Response-efficacy & $0.33^{* *}$ \\
\hline & Self-efficacy & $0.29 * *$ \\
\hline & Perceived cost & $-0.20^{*}$ \\
\hline Step 2 & Habit & $0.35^{* *}$ \\
\hline \multirow[t]{6}{*}{ Step 3} & Habit $\times$ perceived severity & $-0.27 * *$ \\
\hline & Habit $\times$ perceived vulnerability & 0.05 \\
\hline & Habit $\times$ rewards & -0.09 \\
\hline & Habit $\times$ response-efficacy & $-0.12^{*}$ \\
\hline & Habit $\times$ self-efficacy & 0.01 \\
\hline & Habit $\times$ perceived cost & -0.06 \\
\hline
\end{tabular}

Only two of the hypothesized interaction effects were significant. Habit moderated the association between perceived severity and intention $(\beta=-0.27, p<.01)$, and habit moderated the association between response efficacy and intention $(\beta=-0.12, \mathrm{p}<.05)$. Thus, the findings support H8a and H8b, and do not support H8b, H8c, H8e, and H8f. 


\subsection{Post-hoc analyses}

In addition to the examination above, we analyzed the complete antecedent and moderation models using the SEM method (Hair et al., 2006). The psychometric properties of the scales were tested using the Cronbach's alpha (Nunnally \& Bernstein, 1994). Convergent and discriminant validities were verified. The results indicate that the models surpass the acknowledged thresholds for rigorous analysis. Findings are presented in Table 4. Based on the fit indices, the better model fit of the antecedence proposition of habit compared to the moderation model, which, therefore, strengthens our results.

Table 4. Comparison between the fit of the full model of the antecedence and the full model of moderation

\begin{tabular}{|c|c|c|c|c|}
\hline Models & Fit & Antecedence & Moderation & $\begin{array}{l}\text { Better } \\
\text { proposition }\end{array}$ \\
\hline \multirow{5}{*}{$\begin{array}{l}\text { Model 1: } \\
\text { Habit, Perceived } \\
\text { severity, Intention }\end{array}$} & $\chi^{2}$ & 187.56 & 239.42 & \multirow[t]{30}{*}{ Antecedence } \\
\hline & $\overline{\mathrm{Df}}$ & 47 & 230 & \\
\hline & $\mathrm{P}$ & 0.50 & 0.01 & \\
\hline & CFI & 1 & 0.73 & \\
\hline & RMSEA & 0.07 & 0.102 & \\
\hline \multirow{5}{*}{$\begin{array}{l}\text { Model 2: } \\
\text { Habit, Perceived } \\
\text { vulnerability, } \\
\text { Intention }\end{array}$} & $\chi^{2}$ & 203.87 & 377.24 & \\
\hline & Df & 100 & 201 & \\
\hline & $\mathrm{p}$ & 0.48 & 0.01 & \\
\hline & CFI & 0.99 & 0.70 & \\
\hline & RMSEA & 0.00 & 0.14 & \\
\hline \multirow{5}{*}{$\begin{array}{l}\text { Model 3: } \\
\text { Habit, Rewards, } \\
\text { Intention }\end{array}$} & $\chi^{2}$ & 59.25 & 144.87 & \\
\hline & $\frac{\mu}{\mathrm{Df}}$ & 19 & 72 & \\
\hline & $\mathrm{P}$ & 0.3 & 0.02 & \\
\hline & CFI & 0.97 & 0.56 & \\
\hline & RMSEA & 0.06 & 0.100 & \\
\hline \multirow{5}{*}{$\begin{array}{l}\text { Model 4: } \\
\text { Habit, Response } \\
\text { efficacy, Intention }\end{array}$} & $\chi^{2}$ & 118 & 253.33 & \\
\hline & $\tilde{D f}$ & 78 & 261 & \\
\hline & $\mathrm{P}$ & 0.4 & 0.07 & \\
\hline & CFI & 1 & 0.66 & \\
\hline & RMSEA & 0.079 & 0.17 & \\
\hline \multirow{5}{*}{$\begin{array}{l}\text { Model 5: } \\
\text { Habit, Self- } \\
\text { efficacy, Intention }\end{array}$} & $\chi^{2}$ & 212 & 401 & \\
\hline & $\frac{\lambda}{\mathrm{Df}}$ & 145 & 223 & \\
\hline & $\mathrm{P}$ & 0.5 & 0.04 & \\
\hline & CFI & 0.99 & 0.78 & \\
\hline & RMSEA & 0.059 & 0.98 & \\
\hline \multirow{5}{*}{$\begin{array}{l}\text { Model 6: } \\
\text { Habit, Perceived } \\
\text { cost, Intention }\end{array}$} & $\chi^{2}$ & 45 & 124 & \\
\hline & $\frac{\mu}{\mathrm{Df}}$ & 88 & 187 & \\
\hline & $\mathrm{P}$ & 0.44 & 0.09 & \\
\hline & CFI & 1 & 0.82 & \\
\hline & RMSEA & 0.00 & 0.91 & \\
\hline
\end{tabular}

\subsection{Structural-model testing and fsQCA results}

Since the results favored habit as an antecedent of intention to adopt sustainable behavior in HEIs with the full PMT as a mediator. The overall model was tested using SEM methodology. Vulnerability has a positive effect on intention. Thus, H1 was supported $(\lambda=0.15 ; \mathrm{p}<0.03)$. Perceived severity positively affects intention $(\lambda=0.26$; $\mathrm{p}<0.01)$ and rewards negatively affects intention $(\lambda=-0.14 ; \mathrm{p}<0.03)$ as theorized. 
Therefore, hypotheses $\mathrm{H} 2$ and $\mathrm{H} 3$ were both supported. With respect to the hypothesized coping appraisals, response efficacy significantly affected intention $(\lambda=$ $0.22 ; \mathrm{p}<0.01)$. Thus, H4 was supported. Both self-efficacy $(\lambda=0.34 ; \mathrm{p}<0.01)$ and response cost $(\lambda=-0.18 ; \mathrm{p}<0.05)$ affected intention as expected. Therefore, H5and H6 were supported. Finally, for the hypothesized effects of habit on the PMT variables and on the intention, all hypotheses were strongly supported ( $\mathrm{H} 7 \mathrm{a}: \lambda=0.36$; H7b: $\lambda=0.47$; H7c: $\lambda=-0.28$; H7d: $\lambda=0.51$; H7e: $\lambda=0.42$; H7f: $\lambda=0.25$; H7g: $\lambda=-0.32$, and were significant at the $\mathrm{p}<0.01$ level. These results are supported by the results of the hierarchical regression analysis. The most influential factor on intention is Habit followed by the decision maker' $\mathrm{s}$ conviction that he has the aptitude to adopt sustainability (self-efficacy) and the gravity attributable to the non-sustainable behavior (perceived severity).

To assess sufficiency conditions that explain intention to adopt sustainable behavior in HEIs, we use fuzzy set qualitative comparative analysis (fsQCA) (Ganter \& Hecker, 2014), which has important implications for testing theories (Jenson et al., 2015). The study conducts two different types of analyses. The first explores the conditions that lead decision makers to the outcome of intention to adopt sustainable behavior. The second analyzes the conditions that lead decision makers to not adopt sustainable behavior. The two approaches are as follows:

Model 1: Intention $=\mathrm{f}$ (Perceived severity, Perceived vulnerability, Rewards, Responseefficacy, Self-efficacy, Perceived cost, Habit)

Model 2: $\sim$ Intention $=\mathrm{f}$ (Perceived severity, Perceived vulnerability, Rewards, Responseefficacy, Self-efficacy, Perceived cost, Habit)

The symbol $(\sim)$ represents the absence of the outcome ( $\sim$ Intention) or of the condition (e.g., $\sim$ Perceived severity or $\sim$ Habit).

Considering the necessary conditions test, neither of the variables is a necessary condition of intention to adopt sustainable behavior nor intention not to adopt sustainable behavior because all consistency values are under 0.90 (Ragin, 2008, 2009; Ragin and Fiss, 2008). Regarding sufficient conditions, all variables are present for the occurrence of intention and the consistency cutoff on 0.851452 . The intermediate solution indicates seven combinations of causal conditions that can promote intention to adopt sustainable behavior. According to Eng \& Woodside (2012), in fsQCA, a model is informative when consistency is above 0.74 . The coverage $(0.7608214)$ and consistency (0.783740) of the seven conditions seem adequate. Sufficient conditions explain $76 \%$ of the empirical evidence (Woodside, 2014). The seven sufficiency conditions combinations are Perceived severity $\times \sim$ Rewards (raw coverage: 0.264821; consistency: 0.850248), Perceived vulnerability $\times$ Response efficacy (raw coverage: 0.478543; consistency: 0.871648), Self-efficacy $\times \sim$ Cost (raw coverage: 0.536487; consistency: 0.840852), Perceived severity $\times$ Perceived vulnerability $\times \sim$ Cost (raw coverage: 0.497845; consistency: 0.863167), Habit $\times$ Perceived severity $\times$ Self efficacy (raw coverage: 0.574812; consistency: 0.890854), Habit $\times$ Response efficacy $\times$ Self efficacy (raw coverage: 0.347489; consistency : 0.817896), Perceived severity $\times$ Habit $\times$ Perceived vulnerability $\times$ Response efficacy (raw coverage: 0.354871 ; consistency: 0.849347 ). All these conditions are adequate because raw coverage is between 0.25 and 0.65 (Eng \& Woodside, 2012). 


\section{Discussion}

The concern about the adoption of sustainable behavior in institutions of higher education has yet to be definitively resolved. The main objective of this study is to contribute to the advancement of research on SHE. While no previous studies have acknowledged the contribution of PMT in explaining SHE, the findings of this study indicate that there is a link between the emerging literature on SD in HEIs and the more traditional literature on behavior change. The value of the findings of this research lies in demonstrating how the integration of PMT and habit theory can be effective in elucidating sustainable behavior.

In this study, we have proposed how PMT constructs can be conceptualized with regard to sustainable behavior in HEIs. We consider threat appraisal of PMT to refer to an actual risky behavior that has its advantages but effectively conveys negative impacts on quality of life, well being, safety of present and future human generations, physical and cultural resources as well as animal and plant species. Threat appraisal relies on perceived severity of risks and perceived vulnerability to risks engendered by the non-sustainable behavior, and estimated rewards of the non-sustainable behavior. Otherwise, coping appraisal of PMT can be considered as the sustainable behavior which comes at a cost, but may decrease or help keep away from the negative effects, provided that decision makers see themselves able to adopt the sustainable behavior. Coping appraisal relies on perceived response efficacy (i.e., does the sustainable behavior lessen the risks?) and selfefficacy (i.e., can I engage in the sustainable behavior?), and perceived costs of the sustainable behavior.

The results corroborate the findings reported by many researchers (for example, Floyd et al., 2000; Ho, 1998; Milne et al., 2000); not all PMT components had the same effect in predicting behavior. All the concepts were significantly correlated to intention to adopt sustainability, whereas the strengths of the relationships varied for different PMT components (for example, for self-efficacy $\lambda=0.34$ and for vulnerability $\lambda=0.15$ ). This results means that differential consideration must be oriented to the more influential PMT constructs in communication campaigns in order to attain better effects. Particularly, for HEIs, decision makers in MENA must pay more attention to selfefficacy and perceived severity. Specifically, self-efficacy has been documented as one of the most significant factors to promote protective behaviors (Chen et al., 2010; Floyd et al., 2000; Lwin \& Saw, 2007). The findings confirm that perceived efficacy, especially self-efficacy, is among the strongest drivers of intention to adopt sustainability. This suggests the significance of promoting self-efficacy. Obviously, the stress on some PMT components does not indicate that we should overlook other factors to attain a synergetic effect. Similarly, the findings suggest that all six PMT dimensions are significantly correlated with habit and that the strongest effect of Habit is on Intention to adopt sustainability $(\lambda=0.51)$, followed by perceived severity $(\lambda=0.47)$ and response efficacy $(\lambda=0.42)$.

One important result is that we succeeded in developing PMT concepts that integrate relevant items ensuing in highly reliable measurement scales (Cronbach's alpha between 0.72 and 0.88 ). Furthermore, confirmatory factor analysis corroborates the theoretical distinction among the PMT constructs, demonstrating that the items indeed denote 
dissimilar concepts. Future investigations should check the robustness of these results, by testing the PMT in further settings. Furthermore, the PMT proved to be successful in elucidating intention to adopt sustainability. Notably, all PMT constructs appear to distinctively contribute to the explanation of intention. In particular, all of the PMT components are statistically significant predictors of intention in the estimated direction. Well-known theoretical frameworks in environmental psychology (for example, Theory of Planned Behavior (Ajzen, 1991), Norm Activation Model (Schwartz \& Howard, 1981), Value-Belief-Norm Theory (Stern, 2000), and Social Cognitive Theory (Bandura, 2008)) tend to concentrate on the costs and benefits of the adaptive behavior. Thus far, our findings show that decision makers seem to consider the perceived benefits of nonsustainable behavior as well. These results reveal the contribution of PMT to our knowledge of what encourages decision makers to engage in actions to minimize slow onset threats. Future research would explicitly compare the explanatory strengths of different theories to further assess the added value of the PMT.

In addition, the study has shown that habit has a significant effect on all dimensions of PMT. Despite the fact that this result is consistent with theory, we do not find any empirical work that has investigated the relationship between habit and the PMT in the contexts of sustainability generally and in the higher education setting particularly. This demonstrates that habit plays a key role in this the context. Therefore, habit has a pertinent impact on whether decision makers feel that they will be subjected to reprisal if they did not adopt sustainability; habit also has a vital effect on perceived severity of the risk. Past studies investigating sustainability have not applied the entire PMT framework. Besides, the role of past and automatic behavior in the threat appraisal as well as coping responses has not been explored. Habit and PMT variables are two poles apart promoters of behavioral intention. Generally, PMT-based behavior results from a cognitive process (Doane et al., 2016, Hanus, 2016), while habit is an automatic behavioral reaction activated by a situational stimulus devoid of a cognition (Chiu et al., 2012). Therefore, when sustainable behavior is repeatedly accomplished and turns out to be habitual, the need to engage in the cognitive process will be concealed.

The results indicate that the connection between PMT variables and intention to adopt sustainability is quite complex. Adding habit as antecedent in a first step and as moderator in a second step offers a better understanding of this relationship. Future research is required to investigate the intricate relationship between habit, PMT variables, and intention. For instance, it would also be motivating to identify whether, in some conditions, the influence of some PMT variables will be nullified by the influence of habit.

The results support the antecedence hypothesis of Habit upon PMT variables. Consequently, the next defy for sustainable behavior will be how to develop decision makers' habit. For example, past studies show that familiarity, satisfaction and value represent the biggest influential factors of habit formation (Lankton et al., 2010). This signifies that, if sustainable practices can offer superior value for decision makers, it will enhance their satisfaction and accordingly have a positive effect on developing the decision makers' habits. The results show that habit explains additional variance in intention to adopt sustainable behavior. This may be taken as proof that the PMT is not enough and that it would benefit from the addition of more variables. Yet, when the 
quantity of additional variance explained by habit is small, as in the current research, the advantages of adding supplementary concepts in the PMT, in terms of variance explained, has to be weighed in opposition to the loss of parsimony of the model.

Taking into account the additional predictive utility of habit, this study also considered the interacting role of habit within the PMT. Habit was demonstrated to moderate the relationship perceived severity - intention to adopt sustainability, and the relationship response efficacy - intention to adopt sustainability. This goes in parallel with the idea that repeatedly performing a behavior leads to a decrease in the quantity of deliberative processing (Verplanken et al., 1997). So, the strength of the PMT- behavior relationship was shown to become more feeble as the incidence of past behavior augmented. It is obvious that additional analyses of the interaction hypothesis are needed to decide the degree of the moderating effect of past behavior on both PMT variables - intention relationship.

\section{Implications}

The results have significant implications for policy regarding adoption of sustainable behaviors and behavior change. First, policy makers should ensure that decision makers in HEIs recognize well the non-sustainable behavior threats and they must make sure that these threats represent a real problem to their institutions. In addition, it is crucial to tell decision makers that their institutions are probably vulnerable to risks if they do not adopt sustainable behavior. Second, decision makers in HEIs ought to know that sustainable behavior is part of their job responsibility. Third, decision makers should ensure that sustainable behavior and environmental practices are not hard to adopt. Fourth, the findings show that in order to boost acceptability and adoption of sustainable practices, environmental advantages of sustainable behavior should be valorized and the negative effects of non-sustainable behavior highlighted; specifically, by showing the harshness of the negative environmental impacts caused by nonsustainable behavior.

\section{References}

Aaker, D. A., Kumar, V., \& Day, G. S. (2008). Marketing research. John Wiley \& Sons.

Ajzen, I. (1988), Attitudes, personality and behavior, Milton Heynes, England: Open University Press.

Ajzen, I. (1988). Attitudes and personality traits. Attitudes, Personality, and Behavior, 2-24.

Bandura, A. (1991). Social cognitive theory of self-regulation. Organizational behavior and human decision processes, $50(2), 248-287$.

Bandura, A. (2008). The reconstrual of "free will" from the agentic perspective of social cognitive theory. Are we free, 86-127.

Bockarjova, M., \& Steg, L. (2014). Can Protection Motivation Theory predict pro-environmental behavior? Explaining the adoption of electric vehicles in the Netherlands. Global environmental change, 28, 276288.

Bryson, A., Barth, E., \& Dale-Olsen, H. (2013). The effects of organizational change on worker well-being and the moderating role of trade unions. Industrial \& Labor Relations Review, 66(4), 989-1011.

Chen, R.T.H., Maton,K. and Bennett, S. (2011). Absenting discipline: Constructivist approaches in online learning. Disciplinarity: Functional linguistic and sociological perspectives", 129-150. 
Chiu, C.M., Hsu, M.H., Lai, H. and Chang, C.M. (2012). Re-examining the influence of trust on online repeat purchase intention: The moderating role of habit and its antecedents, Decision Support Systems, 53(4), 835-845.

de Guinea, Ana Ortiz, and Lynne Markus, M. (2009). Why break the habit of a lifetime? Rethinking the roles of intention, habit, and emotion in continuing information technology use, Mis Quarterly: 433-444.

Disterheft, A., da Silva Caeiro, S.S.F., Ramos, M.R. and de Miranda Azeiteiro, U.M. (2012).Environmental Management Systems (EMS) implementation processes and practices in European higher education institutions-Top-down versus participatory approaches, Journal of Cleaner Production, 31, 80-90.

Floyd, S., Handley, M., Padhye, J. and Widmer, J. (2000). Equation-based congestion control for unicast applications, ACM SIGCOMM Computer Communication Review, 30 (4), 43-56.

Frynas, J.G. and Yamahaki, C. (2016). Corporate social responsibility: review and roadmap of theoretical perspectives, Business Ethics: A European Review, 25(3), 258-285.

Gitsham, M. and Lenssen, G. (2009), Developing the global leader of tomorrow.

Grothmann, T. and Reusswig, F. (2006). People at risk of flooding: why some residents take precautionary action while others do not, Natural hazards, 38(1-2), 101-120.

Hanus, B. and Wu, Y.A. (2016). Impact of Users' Security Awareness on Desktop Security Behavior: A Protection Motivation Theory Perspective, Information Systems Management, 33(1), 2-16.

Jenson, I., Leith, P., Doyle,R., West,J. and Miles, M.P. (2016). Testing innovation systems theory using Qualitative Comparative Analysis, Journal of Business Research, Vol. 69(4), 1283-1287.

Khalifa, M. and Liu, V. (2007). Online consumer retention: contingent effects of online shopping habit and online shopping experience, European Journal of Information Systems, 16(6), 780-792.

Kuckertz, A. and Wagner, M. (2010). The influence of sustainability orientation on entrepreneurial intentions-Investigating the role of business experience, Journal of Business Venturing, 25(5), 524539.

Lankton, N.K., Wilson, E.V. and Mao, E. (2010). Antecedents and determinants of information technology habit", Information \& Management, 47(5), 300-307.

Limayenm, M., Hirt, S.G. and Cheung, C.M. (2003). Habit in the context of IS continuance: theory extension and scale development, ECIS 2003 Proceedings, 90.

Lwin, M.O. and Saw, S.M. (2007). Protecting children from myopia: a PMT perspective for improving health marketing communications, Journal of health communication, 12(3), 251-268.

Milne, S., Sheeran, P. and Orbell, S. (2000). Prediction and intervention in health-related behavior: A meta-analytic review of protection motivation theory, Journal of Applied Social Psychology, 30(1), 106143.

Norman, P. and Conner, M. (2006). The theory of planned behaviour and binge drinking: Assessing the moderating role of past behaviour within the theory of planned behaviour, British journal of health psychology, 11(1), 55-70.

Ouellette, J.A. and Wood, W. (1998), Habit and intention in everyday life: the multiple processes by which past behavior predicts future behavior, Psychological bulletin, 124(1), 54-74.

Plotnikoff, R.C. and Higginbotham, N. (2002). Protection motivation theory and exercise behaviour change for the prevention of heart disease in a high-risk, Australian representative community sample of adults, Psychology, health \& medicine, 7(1), 87-98.

Rogers, R.W. (1983). Cognitive and physiological processes in fear appeals and attitude change: A revised theory of protection motivation, Social psychophysiology, 153-176.

Scarpa, R. and Thiene, M. (2011). Organic food choices and Protection Motivation Theory: Addressing the psy.hological sources of heterogeneity, Food quality and preference, 22(6), 532-541.

Schwartz, S.H. and Howard, J.A. (1981). A normative decision-making model of altruism, Altruism and belping behavior, 189-211.

Sheeran, P. (2002). Intention-behavior relations: A conceptual and empirical review, European review of social psychology, 12(1), 1-36. 
Sobel, M.E. (1982). "Asymptotic confidence intervals for indirect effects in structural equation models", Sociological methodology, 13, 290-312.

Stern, P.C. (2000). Psychology and the science of human-environment interactions, American psychologist, 55(5), 523.

Triandis, H.C. (1977). Interpersonal behavior. Brooks/Cole Pub. Co.

Tsai, J., Sippel, L.M., Mota, N., Southwick, S.M. and Pietrzak, R.H. (2016). Longitudinal course of posttraumatic growth among US Military Veterans: Results from the National Health and Resilience in Veterans Study, Depression and anxiety, 33(1), 9-18.

Vance, A., Siponen, M. and Pahnila, S. (2012). Motivating IS security compliance: insights from habit and protection motivation theory, Information \& Management, 49(3), 190-198.

Verplanken, B. and Aarts, H. (1999). Habit, attitude, and planned behaviour: is habit an empty construct or an interesting case of goal-directed automaticity? European review of social psychology, 10 (1), 101-134.

Verplanken, B., Aarts, H. and Van Knippenberg, A. (1997). Habit, information acquisition, and the process of making travel mode choices, European journal of social psychology, 27(5), 539-560.

Verplanken, B. and Orbell, S. (2003). Reflections on Past Behavior: A Self-Report Index of Habit Strength, Journal of Applied Social Psychology, 33(6), 1313-1330.

Zhao, G., Cavusgil, E. and Zhao, Y. (2016). A protection motivation explanation of base-of-pyramid consumers' environmental sustainability, Journal of Environmental Psychology, 45,116-126.

\section{APPENDIX}

Table: Prior studies on Behavior Change for sustainability in higher education

\begin{tabular}{|c|c|c|c|c|}
\hline Studies & Objectives & Concepts & Theories & Key findings \\
\hline $\begin{array}{l}\text { McNamara } \\
(2008)\end{array}$ & $\begin{array}{l}\text { - To identify the factors } \\
\text { leading a successful } \\
\text { change effort to foster } \\
\text { sustainability. } \\
\text { - To identify the } \\
\text { processes that assist } \\
\text { higher education } \\
\text { institutions in efforts to } \\
\text { implement sustainable } \\
\text { changes. }\end{array}$ & $\begin{array}{l}\text { - Internal Conditions } \\
\text { - External Environments } \\
\text { - Leadership } \\
\text { Characteristics } \\
\text { - Change Process } \\
\text { - Engagement of } \\
\text { Constituents } \\
\text { - Facilitated Learning } \\
\text { - Change Characteristics }\end{array}$ & $\varnothing^{*}$ & $\begin{array}{l}\text { The key themes that offer advice } \\
\text { to those interested by } \\
\text { sustainability are: } \\
\text { - Obtain backing of the } \\
\text { president's office. } \\
\text { - Institutionalize the sustainability } \\
\text { initiative. } \\
\text { - Develop a sustainability plan. } \\
\text { - Allocate resources necessary to } \\
\text { achieve the plan. } \\
\text { - Develop student commitment. } \\
\text { - Adopt a holistic approach to } \\
\text { sustainability. } \\
\text { - Maintain the enthusiasm into } \\
\text { the future. }\end{array}$ \\
\hline $\begin{array}{l}\text { Arbuthnott } \\
(2009)\end{array}$ & $\begin{array}{l}\text { - To demonstrate that } \\
\text { change in attitudes does } \\
\text { not correlate all the time } \\
\text { with change in behavior. }\end{array}$ & $\begin{array}{l}\text { - Intention specificity } \\
\text { - Perceived control } \\
\text { - Task difficulty } \\
\text { - Regulations/ incentives } \\
\text { - Habit } \\
\text { - Self-regulation depletion }\end{array}$ & $\varnothing$ & $\begin{array}{l}\text { - Attitude-behavior correlations } \\
\text { are mediated by contextual } \\
\text { conditions and personal factors. }\end{array}$ \\
\hline $\begin{array}{l}\text { Fadeeva } \\
\text { and } \\
\text { Mochizuki } \\
(2010)\end{array}$ & $\begin{array}{lll}\text { - To discusses } & \text { the } \\
\text { changing landscape } & \text { for } \\
\text { knowledge creation. } & \end{array}$ & $\begin{array}{l}\text { - Ranking } \\
\text { - Appraisal } \\
\text { - Transformation }\end{array}$ & $\varnothing$ & $\begin{array}{l}\text { - The conventional ranking and } \\
\text { assessment systems, if modified, } \\
\text { could be an important strength } \\
\text { for transformation towards a } \\
\text { more sustainable future. }\end{array}$ \\
\hline $\begin{array}{l}\text { Benn and } \\
\text { Martin } \\
(2010)\end{array}$ & $\begin{array}{l}\text { To study the } \\
\text { organizational learning } \\
\text { and change mechanisms. }\end{array}$ & $\begin{array}{l}\text { - Social context } \\
\text { - Economic context } \\
\text { - Ecological context } \\
\text { - Organizational change } \\
\text { - Organizational learning } \\
\end{array}$ & $\varnothing$ & $\begin{array}{l}\text { - Experience is important in order } \\
\text { to further share understandings of } \\
\text { sustainability. }\end{array}$ \\
\hline $\begin{array}{l}\text { Chen et al. } \\
\text { (2011) }\end{array}$ & $\begin{array}{l}\text { - To examine college and } \\
\text { university dining services }\end{array}$ & $\begin{array}{l}\text { - Intention } \\
\text { - Attitude }\end{array}$ & $\begin{array}{l}\text { Theory } \\
\text { of }\end{array}$ & $\begin{array}{l}\text { - Subjective Norm had the most } \\
\text { influential factor on intention to }\end{array}$ \\
\hline
\end{tabular}




\section{Sultan O. Almarshad}

\begin{tabular}{|c|c|c|c|c|}
\hline & $\begin{array}{l}\text { administrators' intention } \\
\text { to adopt sustainable } \\
\text { practices. }\end{array}$ & $\begin{array}{l}\text { - Subjective norm } \\
\text { - Perceived behavior } \\
\text { control } \\
\text { - Personal norm } \\
\text { - Knowledge } \\
\text { - Personal value } \\
\text { - Past experience }\end{array}$ & $\begin{array}{l}\text { Planned } \\
\text { Behavior }\end{array}$ & $\begin{array}{l}\text { adopt sustainability, followed by } \\
\text { attitude and personal norm. }\end{array}$ \\
\hline $\begin{array}{l}\text { Wright and } \\
\text { Wilton } \\
(2012)\end{array}$ & $\begin{array}{l}\text { - to investigate how a } \\
\text { cohort of facilities } \\
\text { management directors } \\
\text { conceptualize } \\
\text { sustainability } \\
\text { - to identify the perceived } \\
\text { barriers to implement } \\
\text { sustainability. }\end{array}$ & $\begin{array}{l}\text { - Resistance to change } \\
\text { - sustainability }\end{array}$ & $\varnothing$ & $\begin{array}{l}\text { - Not all facilities management } \\
\text { directors had a clear idea of what } \\
\text { sustainable universities are. } \\
\text { - Environmental sustainability } \\
\text { was the most important aspect of } \\
\text { sustainable development. } \\
\text { - Financial and resource based, as } \\
\text { well as resistance to change are } \\
\text { the biggest barrier to } \\
\text { sustainability. }\end{array}$ \\
\hline $\begin{array}{l}\text { Mosher and } \\
\text { Desrochers } \\
(2012)\end{array}$ & $\begin{array}{l}\text { - To evaluate the } \\
\text { effectiveness of } \\
\text { sustainability information } \\
\text { and strategies to change } \\
\text { pro-environmental } \\
\text { behavior. }\end{array}$ & $\begin{array}{l}\text { - Attitudes } \\
\text { - Knowledge } \\
\text { - Cues in the environment } \\
\text { - Costs-Benefits } \\
\text { - Commitment to } \\
\text { behavior change }\end{array}$ & $\varnothing$ & $\begin{array}{l}\text { - The pro-e training increases } \\
\text { energy conservation behavior. }\end{array}$ \\
\hline $\begin{array}{l}\text { Connell } \\
\text { and Kozar } \\
(2012)\end{array}$ & $\begin{array}{l}\text { - To analyze changes in } \\
\text { undergraduate student } \\
\text { knowledge of issues of } \\
\text { sustainability. }\end{array}$ & $\begin{array}{l}\text { - Socially responsible } \\
\text { knowledge } \\
\text { - Environmental } \\
\text { knowledge } \\
\text { - Apparel-purchasing } \\
\text { behaviors }\end{array}$ & $\varnothing$ & $\begin{array}{l}\text { - Pre and post comparisons } \\
\text { revealed significant changes in } \\
\text { students' knowledge of social and } \\
\text { environmental issues. } \\
\text { - The study found no significant } \\
\text { adjustments in apparel purchasing } \\
\text { behavior. } \\
\text { - No significant relationship } \\
\text { between knowledge and } \\
\text { purchasing behavior. }\end{array}$ \\
\hline $\begin{array}{l}\text { Cole and } \\
\text { Fieselman } \\
(2013)\end{array}$ & $\begin{array}{l}\text { - To design a campaign to } \\
\text { foster sustainable } \\
\text { behavior change. }\end{array}$ & $\begin{array}{l}\text { - Social marketing } \\
\text { - Communities } \\
\text { - Waste minimisation } \\
\text { - Behavior change } \\
\text { - Community-based social } \\
\text { marketing } \\
\text { - Recycling } \\
\text { - Paper reduction } \\
\text { - Environmentally- } \\
\text { preferable purchasing }\end{array}$ & $\varnothing$ & $\begin{array}{l}74 \% \text { of staff and faculty changed } \\
\text { their behavior because of the } \\
\text { campaign. }\end{array}$ \\
\hline $\begin{array}{l}\text { Parece et al. } \\
(2013)\end{array}$ & $\begin{array}{l}\text { To explore whether the } \\
\text { behavior change when } \\
\text { various conservation } \\
\text { strategies are introduced. }\end{array}$ & $\begin{array}{l}\text { - Natural resources } \\
\text { - Energy conservation } \\
\text { - Environmentally } \\
\text { relevant behavior } \\
\text { - University residence } \\
\text { halls }\end{array}$ & $\begin{array}{l}\text { - Social } \\
\text { norm } \\
\text { theory } \\
-\quad \text { Value- } \\
\text { belief } \\
\text { norm } \\
\text { theory }\end{array}$ & $\begin{array}{l}\text { - Additive strategies did not } \\
\text { produce higher reductions. }\end{array}$ \\
\hline $\begin{array}{l}\text { Owen et al. } \\
(2013)\end{array}$ & $\begin{array}{l}\text { - To outline a process for } \\
\text { the inclusion of climate } \\
\text { change adaption. }\end{array}$ & $\begin{array}{l}\text { - Climate change } \\
\text { adaptation } \\
\text { - Climate change planning } \\
\text { - Adaptation assessment }\end{array}$ & $\varnothing$ & $\begin{array}{l}\text { - Key vulnerabilities fell into three } \\
\text { main areas of concern: energy, } \\
\text { transportation, and built } \\
\text { environment. }\end{array}$ \\
\hline $\begin{array}{l}\text { Savageau } \\
(2013)\end{array}$ & $\begin{array}{l}\text { - To lay the groundwork } \\
\text { for behavioral change for } \\
\text { sustainability. }\end{array}$ & $\begin{array}{l}\text { - Sustainable design - } \\
\text { - Resource consumption } \\
\text { - Waste audit } \\
\text { - Self-reflection } \\
\text { - Behavioral change } \\
\end{array}$ & $\varnothing$ & $\begin{array}{l}\text { - Students are motivated to } \\
\text { change behaviors. }\end{array}$ \\
\hline $\begin{array}{l}\text { Exter et al. } \\
(2013)\end{array}$ & $\begin{array}{l}\text { - to capture, codify and } \\
\text { communicate an implicit }\end{array}$ & $\begin{array}{l}\text { - Corporate responsibility } \\
\text { - Organizational change }\end{array}$ & $\begin{array}{l}\text { - Change } \\
\text { managem }\end{array}$ & $\begin{array}{lrrr}- & \text { The } & \text { implicit } & \text { change- } \\
\text { management } & \text { process } & \text { had }\end{array}$ \\
\hline
\end{tabular}




\begin{tabular}{|c|c|c|c|c|}
\hline & $\begin{array}{l}\text { change management } \\
\text { process. }\end{array}$ & - Change management & $\begin{array}{l}\text { ent } \\
\text { theory }\end{array}$ & $\begin{array}{l}\text { unconsciously mobilized a variety } \\
\text { of tactics. }\end{array}$ \\
\hline $\begin{array}{l}\text { Horhota et } \\
\text { al. }(2014)\end{array}$ & $\begin{array}{l}\text { - To assess the behavioral } \\
\text { barriers to sustainability. } \\
\text { - To foster behavioral } \\
\text { change. }\end{array}$ & $\begin{array}{l}\text { - Assessment } \\
\text { - Behavioral change } \\
\text { - Campus perceptions } \\
\text { - Sustainability barriers } \\
\text { - Sustainable behavior }\end{array}$ & $\varnothing$ & $\begin{array}{l}\text { - Four key barriers are identified: } \\
\text { communication/awareness, } \\
\text { inconvenience, financial concerns } \\
\text { and lack of engagement. }\end{array}$ \\
\hline $\begin{array}{l}\text { Parris } \\
(2015)\end{array}$ & $\begin{array}{l}\text { - To examine the effects } \\
\text { of living in "green" } \\
\text { dorms on students" } \\
\text { environmentally } \\
\text { responsible behaviors. }\end{array}$ & $\begin{array}{l}\text { - Environmental identity } \\
\text { - Environmentally } \\
\text { responsible behavior } \\
\text { - Peer influence } \\
\text { - Sustainable dorms }\end{array}$ & $\begin{array}{l}\text { - Identity } \\
\text { theory }\end{array}$ & $\begin{array}{l}\text { - Students who live in "green" } \\
\text { dorms engage in more recycling } \\
\text { and advocacy behaviors than } \\
\text { students in conventional dorms. } \\
\text { - Environmental identity and } \\
\text { perceived behavior modeling by } \\
\text { peers positively affect recycling, } \\
\text { advocacy and conservation. } \\
\text { - An interaction between dorm } \\
\text { and identity whereby students } \\
\text { with weak environmental } \\
\text { identities experience a greater } \\
\text { increase in ERBs from living in } \\
\text { green dorms than do students } \\
\text { with strong environmental } \\
\text { identities. }\end{array}$ \\
\hline $\begin{array}{l}\text { Sintov et } \\
\text { al. }(2016)\end{array}$ & $\begin{array}{l}\text { - To evaluate the impact } \\
\text { of a competition-based } \\
\text { intervention on energy } \\
\text { consumption. } \\
\text { - To examine } \\
\text { psychosocial correlates of } \\
\text { behavior change. }\end{array}$ & $\begin{array}{l}\text { - Pro-environmental } \\
\text { behavior } \\
\text { - Self-efficacy } \\
\text { - Behavior change } \\
\text { - Social norms } \\
\text { - Group identification }\end{array}$ & $\begin{array}{l}\text { - Theory } \\
\text { of } \\
\text { Planned } \\
\text { Behavior } \\
\text { - Self- } \\
\text { Determin } \\
\text { ation } \\
\text { Theory }\end{array}$ & $\begin{array}{l}\text { - Changes in pro-environmental } \\
\text { behavior were associated with } \\
\text { changes in level of group } \\
\text { identification and perceived social } \\
\text { norms. }\end{array}$ \\
\hline $\begin{array}{l}\text { Pollard } \\
(2016)\end{array}$ & $\begin{array}{l}\text { - To explore the drivers } \\
\text { of computer-related } \\
\text { sustainability behavior. }\end{array}$ & $\begin{array}{l}\text { - Adaptation } \\
\text { - Technology } \\
\text { - Energy reduction }\end{array}$ & $\varnothing$ & $\begin{array}{l}\text { - The drivers to save energy at } \\
\text { work were sense of social } \\
\text { responsibility and the recognition } \\
\text { of the need to reduce energy. }\end{array}$ \\
\hline
\end{tabular}

${ }^{*} \varnothing=$ the study is not guided by theories. 